\title{
AGENCY COSTS IN LAW-FIRM SELECTION: ARE COMPANIES UNDER-SPENDING ON COUNSEL?
}

\author{
Elisabeth de Fontenay* \\ CAP. MKTS. L. J. _ (forthcoming)
}

\begin{abstract}
A growing body of literature examines whether corporate clients derive sufficient value from the law firms that they engage. Yet little attention has been paid to whether clients optimally select among law firms in the first place. One entry-point is to identify discrepancies in the quality of counsel selected by different corporate clients for the very same work. Using a large sample of loans, this Article finds that major U.S. public companies select lower-ranked law firms for their financing transactions than do private equity-owned companies, controlling for various deal characteristics. While some of this discrepancy can be attributed to value-maximizing behavior, agency and other information problems within public companies may distort their choice of counsel. Contrary to the thrust of existing commentary, U.S. public companies may well be spending too little on outside counsel.
\end{abstract}

\section{TABLE OF CONTENTS}

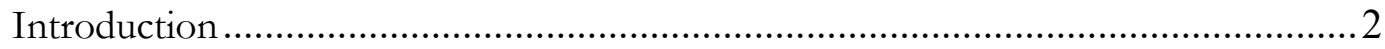

I. Law Firm Selection in Practice: Private Equity Firms vs. Public Companies......... 5

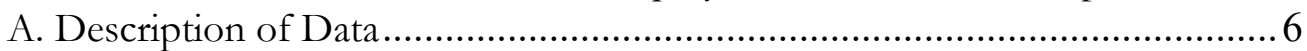

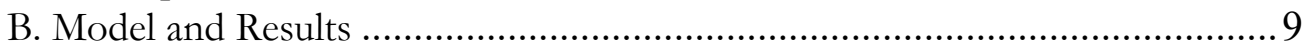

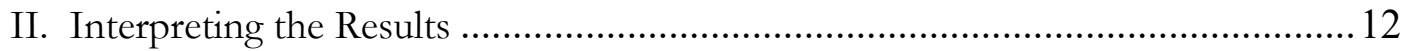

A. The Private Equity Perspective ............................................................... 13

B. Is The Private Equity Calculus Generalizable? ........................................... 14

C. The Public Company Perspective ............................................................. 16

1. General Counsel Decision-Making................................................... 16

2. Relationship Lawyering 2.0 ?...................................................... 19

* Associate Professor, Duke University School of Law (defontenay@law.duke.edu). For comments and discussions, thanks are due to Jim Cox, John Coyle, Catherine de Fontenay, Deborah DeMott, Mitu Gulati, Kim Krawiec, Andrew Verstein, and participants in workshops at Duke University, Harvard University, New York University, Stanford University, the University of Colorado, the University of Pennsylvania, and Yale University. Mitchell Brunson and Jonathan $\mathrm{Ng}$ provided excellent research assistance. All errors are mine. 
III. Case Study: A Tale of Four Financings................................................ 21

A. Berkshire Hathaway ....................................................................... 23

B. Philip Morris International and Northrop Grumman.............................. 25

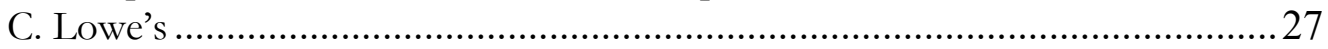

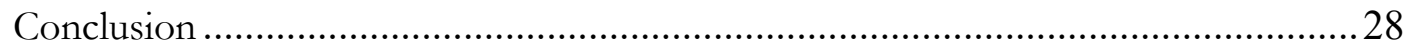

\section{INTRODUCTION}

Corporate clients select their law firms for myriad reasons, some of which are likely to be value-maximizing, and some of which are not. The economic stakes are high: to the extent that clients fail to make first-best decisions in hiring counsel, they may derive needlessly poor outcomes from the legal services that they purchase, while law firms earn large rents at their clients' expense. Yet because we lack straightforward measures of the quality of law firms' output, we are generally left either to assume that clients choose their counsel rationally or to suspect that they do not, depending solely on our priors about the efficiency of markets.

This Article takes an indirect tack in broaching the problem. It begins with a more readily observable inquiry — whether different types of corporate clients select different quality counsel for the very same work. If so, we have evidence that, at the very least, law-firm selection is non-random. Further, we will be left with a far simpler task than assessing the efficiency of law firm selection in general. The set of plausible factors driving a discrepancy in choice of counsel between different types of clients is likely to be comparatively small. Once identified, these factors can be classified according to whether they are likely to be value-maximizing for the client, providing narrower testable hypotheses for future work.

This Article focuses on two types of clients having very different goals and governance, but with the financial means to select among a wide range of law firms: 1) large private equity firms and 2) major public companies. ${ }^{1}$ Given their prominence in large financings and acquisitions, private equity firms have increasingly captured the time and attention of elite law firms in the United States and abroad. Private equity firms tend to be leanly staffed ${ }^{2}$ and thus to rely heavily on outside counsel. Large public companies, by contrast, may have large teams of in-house lawyers and are therefore less reliant on outside counsel for certain types of work. ${ }^{3}$ These and other differences between the

1 "Private equity" as used herein refers only to investment funds whose focus is leveraged, majority-stake investments in mature businesses - that is, leveraged buyout funds. Thus, for example, venture capital is not treated here as private equity.

2 See Michael C. Jensen, Eclipse of the Public Corporation, HARv. Bus. REv., Sept.-Oct. 1989, at 70 .

3 See, e.g., Abram Chayes \& Antonia H. Chayes, Corporate Counsel and the Elite Law Firm, 37 
two may manifest in different preferences for the quality of outside counsel that they select.

Various theories have been advanced for the value added by lawyers in corporate transactions. Gilson (1984) describes transactional lawyers as "transaction-cost engineers" who, even in the absence of regulation, can increase the transaction value by structuring the transaction and crafting contract terms so as to minimize the parties' aggregate transaction costs (including in particular their information costs). ${ }^{4}$ Kraakman and others suggest that law firms act as reputational intermediaries in corporate transactions: their reputation plays a certification role that allows parties to reach an agreement at lower cost. $^{5}$ Still others argue that transactional lawyers primarily serve as regulatory experts. ${ }^{6}$ When the focus narrows to law firms with high-market-share transactional practices, their knowledge of the current "market" terms for a particular type of transaction can also create value." As market information experts, they should be able to negotiate transaction terms that yield more transaction surplus for their clients. ${ }^{8}$

Using a large sample of syndicated loan transactions, I find that private equity-owned companies are substantially more likely to engage top-ranked borrower's counsel than are their public-company counterparts, controlling for various loan characteristics. Why might private equity sponsors be more willing to pay for elite law firms than much larger organizations such as Fortune 500 companies, for the very same types of transactions? Conversely, what explains the relative reticence of major corporations to engage top-tier

STAN. L. REV. 277, 277-80 (1985) (describing the increasing importance of in-house counsel in large corporations).

4 See Ronald J. Gilson, Value Creation by Business Lawyers: Legal Skills and Asset Pricing, 94 YALE L.J. 239 (1984).

5 See Reinier H. Kraakman, Gatekeepers: The Anatomy of a Third-Party Enforcement Strategy, 2 J.L. ECON. \& ORG. 53, 61 n.20 (1986); Karl S. Okamoto, Reputation and the Value of Lawyers, 74 OR. L. REV. 15, 18-19 (1995); Gilson, supra note 4, at 290-93; Larry E. Ribstein, Ethical Rules, Agency Costs, and Law Firm Structure, 84 VA. L. REV. 1707, 1739-40 (1998). For empirical work testing the gatekeeper hypothesis, see Royce de R. Barondes et al., Underwriters' Counsel as Gatekeeper or Turnstile: An Empirical Analysis of Law Firm Prestige and Performance in IPOs, 2 CAP. MKTS. L.J. 164, 165 (2007) (finding that higher-quality law firms preserve some independence relative to the issuer in IPOs); Michael Bradley et al., Lawyers: Gatekeepers of the Sovereign Debt Market?, 38 INT'L. REV. L. \& ECON. 150, 162 (2014) (finding no evidence in the sovereign debt markets that law firms act as reputational intermediaries).

6 See Victor Fleischer, Regulatory Arbitrage, 89 TEX. L. REV. 227, 239 (2010); Steven L. Schwarcz, Explaining the Value of Transactional Lawyering, 12 STAN. J.L. BUS. \& FIN. 486, 500 (2007).

7 See Elisabeth de Fontenay, Law Firm Selection and the Value of Transactional Lanyering, $41 \mathrm{~J}$. Corp. L. 101 (forthcoming 2016). See also Christel Karsten, Ulrike Malmendier \& Zacharias Sautner, M\&A Negotiations and Lawyer Expertise (Mar. 2015) (unpublished manuscript), http://ssrn.com/abstract $=2576866$ (finding that more experienced M\&A lawyers obtain better contract terms for their clients).

${ }^{8} I d$. 
law firms?

In considering these questions, we first observe that private equity firms are relatively well incentivized to select counsel for their portfolio companies that maximizes their expected value from the transaction. Private equity investments are typically highly leveraged, ${ }^{9}$ meaning that any improvement in transaction terms that counsel can obtain results in a relatively larger economic return. Further, private equity sponsors benefit more directly from such increased returns than do the public-company agents-typically, general counsels-responsible for selecting outside counsel. Private equity sponsors commonly receive twenty percent of the profits from their portfolio-company transactions (the "carry"), ${ }^{10}$ which is then shared among a relatively small number of individuals. Such high-powered incentives to maximize transaction value contrast with the relatively low-powered incentives faced by publiccompany general counsels. ${ }^{11}$

Not only are private equity firms better incentivized to select counsel optimally, they are arguably better able to do so. As sophisticated, repeat players with respect to leveraged acquisitions, ${ }^{12}$ they can benchmark their outside counsel's performance across a sizable volume of transactions. Thus, overall, private equity firms internalize both the costs (higher legal fees) and the benefits (the expectation of a better economic deal) of hiring top-tier law firms relatively well. From the outset, then, their revealed preference for elite counsel suggests that it is likely to be value-maximizing.

The picture for public companies is murkier. Major public companies face a classic "make-or-buy" decision when it comes to transactional work: they can engage a law firm or rely on in-house counsel. ${ }^{13}$ Yet framing the make-or-buy decision as a binary choice is misleading in this context. In practice, the difficulty lies in selecting from a wide range in quality of outside counsel, once the decision to "buy" has been made. This Article's empirical result raises the possibility that public companies are selecting an inefficiently low quality of legal work for their transactions. Stated differently, a general counsel's bias toward "making" legal work in-house may manifest as a tendency not only to forgo (or under-utilize) outside counsel for certain work, but also to select lower-quality outside counsel than is optimal for the company.

9 See Steven N. Kaplan \& Per Strömberg, Leveraged Buyouts and Private Equity, 23 J. ECON. PERSP. 121, 124 (2009).

10 See Victor Fleischer, Two and Twenty: Taxing Partnership Profits in Private Equity Funds, 83 N.Y.U. L. REV. 1, 5 (2008).

11 See Oliver E. Williamson, The Economic Institutions of Capitalism: Firm, MARKETS, AND RELATIONAL CONTRACTING (1985) (describing the high-powered incentives provided by market transactions versus the low-powered incentives within firms).

12 See, e.g., Elisabeth de Fontenay, Private Equity Firms as Gatekeepers, 33 REV. BANKING \& FIN. L. 115 (2013).

13 See Steven L. Schwarcz, To Make or to Buy: In-House Lawyering and Value Creation, 33 J. CORP. L. 497 (2008). 
To be sure, in-house counsel at public companies can help monitor outside law firms' work, ${ }^{14}$ thus potentially increasing the value that outside counsel provides once a law firm has been engaged. Yet there are reasons to doubt whether public-company general counsels optimally select among law firms in the first instance. Particularly for one-off transactions, general counsels may not be correctly incentivized to make value-maximizing choices. Information, agency, and influence costs within public companies may drive general counsels to steer transactional work to cheaper firms or to in-house counsel, even when doing so is not in shareholders' best interests. ${ }^{15}$ This raises the surprising possibility that, contrary to the prevailing view, major U.S. public companies may in fact be under-spending on legal services. ${ }^{16}$

The Article proceeds as follows. Part I describes the data and regression model and presents the finding of a substantial discrepancy in the quality of counsel selected by private equity-owned companies and public companies. Part II discusses plausible explanations for the differential. Finally, Part III assesses these explanations in practice, through a case study of four multibillion-dollar loan transactions for which the public-company borrowers chose law firms outside the circle of elite borrower's counsel.

\section{LaW Firm Selection in Practice: Private Equity Firms vs. Public COMPANIES}

This Part provides evidence that private equity sponsors are more likely to engage top-tier law firms to negotiate their syndicated-loan financings (or "bank debt") ${ }^{17}$ than are public companies.

14 See, e.g., Robert Eli Rosen, The Inside Counsel Movement, Professional Judgment and Organizational Representation, 64 IND. L.J. 479, 487 (1989)

15 See infra Part II.B.C.

16 Contra Burk \& David McGowan, Big But Brittle: Economic Perspectives on the Future of the Law Firm in the New Economy, 2011 Colum. Bus. L. Rev. 1 (identifying excessive fees as one of the threats to the future of major corporate law firms).

17 Syndicated loans are typically senior secured commercial loans that are arranged by a major investment or commercial bank and funded by a large group of bank and non-bank lenders. See Allison A. Taylor \& Ruth Yang, Evolution of the Primary and Secondary Leveraged Loan Markets, in The Handbook of LoAn Syndications AND Trading 21, 23-24 (Allison Taylor \& Alicia Sansone eds., 2007); Arthur E. Wilmarth, Jr., The Dark Side of Universal Banking: Financial Conglomerates and the Origins of the Subprime Financial Crisis, 41 CONN. L. REV. 963, 982 (2009). Relative to other major corporate transactions, syndicated loans are lightly regulated in the United States and otherwise raise little risk of litigation. Most notably, syndicated loans are not treated as securities, notwithstanding that they may be held and traded by large numbers of investors. See Elisabeth de Fontenay, Do the Securities Laws Matter? The Rise of the Leveraged Loan Market, 39 J. CORP. L. 725, 747 (2014); Sung Eun (Summer) Kim, Managing Regulatory Blindspots, 32 YALE J. ON REG. 89 (2015). To be sure, a syndicated loan transaction may involve litigation risk if it occurs in connection with another high-stakes transaction, such as an acquisition. 


\section{A. Description of Data}

The initial sample consists of 4,201 credit agreements for U.S. syndicated loans issued between July 2011 and May 2016, from the Practical Law database. ${ }^{18}$ This database is limited to credit agreements that were publicly filed with the U.S. Securities and Exchange Commission. Relative to the complete universe of syndicated loans, therefore, larger loans are likely overrepresented in our sample, while loans involving private companies (including, notably, loans to private-equity-owned companies) are underrepresented. ${ }^{19}$ After excluding loans totaling less than $\$ 50$ million in principal amount and loans used for debtor-in-possession (DIP) financing, we are left with a sample of 4,164 credit agreements.

For each loan, the primary characteristics of interest are 1) whether the borrower was sponsored by a private-equity firm and 2) the quality of the borrower's law firm (if any). Because law-firm quality is not directly observable, two categories of metrics are constructed here as proxies: rankings based on market share (designed to capture law firms' experience with the applicable type of transaction) and rankings based on reputation among market participants. In the first category, we derive each law firm's share of borrower-side legal representation for syndicated loan deals (or leveraged syndicated loan deals, depending on the regression sample used), where market share is based here on aggregate dollar-amount of loans. The loan amounts for each law firm are obtained from Bloomberg and independently calculated within our sample of Practical Law credit agreements, creating two separate market-share metrics. ${ }^{20}$

Unlike what we observe with law-firm league tables for mergers and acquisitions, the set of top borrower-side law firms by market share for syndicated loans (and leveraged syndicated loans) is somewhat variable from year to year. Given that, we instead rank firms in each year based on a calculation of their aggregate market share of borrower-side representation

18 What's Market-Credit Agreements: Comprehensive Deal Database, PRAC. L., http://us.practicallaw.com/resources/us-whats-market.

19 This sample bias should not be problematic for our analysis, however. First, we explicitly restrict the sample to large loans (greater than $\$ 50$ million in principal amount) in any event, in order to ensure that all borrowers in the sample have the ability to pay for a wide range in quality of counsel. Second, relying solely on publicly-filed credit agreements implies that, to the extent the borrower is private-equity-sponsored, that private equity firm is likely to be larger than average. (For example, many such credit agreements likely involve going-private transactions.) The empirical tests control for loan size, however, which should achieve some measure of normalization between the private equity firms and the public companies in the sample.

20 The Bloomberg data is based on self-reporting by law firms, and covers all syndicated loans (or leveraged syndicated loans), rather than just loans publicly filed with the SEC. 
over the previous several years. ${ }^{21}$ Finally, a firm is coded as top-ranked in a given year if it fell within the top 10, 15, or 20 law firms for that year.

Our reputation-based measure of the quality of counsel is based on the Chambers and Partners rankings of U.S. law firms. We code a borrower's law firm as top-ranked in any given year if it was included within any tier of the Chambers "Banking \& Finance: Nationwide" rankings for the prior year. ${ }^{22}$ The Chambers rankings cover a total of 21 law firms in each year. ${ }^{23}$

Setting the cut-off for elite-quality law firms at approximately the top 20 (or fewer) is justified by the fact that borrower-side representation is highly concentrated in the syndicated loan market. Figure 1 depicts law firms' priorfour-year market share of borrower-side leveraged-loan representation, in ranked order for 2016. While the first few firms each hold a significant share of the market, market share falls off rapidly thereafter. The top twenty firms represent almost $60 \%$ of the market in aggregate. ${ }^{24}$

Figure 1. Top Law Firms' Market Share of Borrower-Side Representation for Leveraged Loans (2016).

21 The ranking based on Bloomberg data looks back to the prior four years of loan volume, while the ranking using the Practical Law sample looks back only two years, because the Practical Law database only begins in 2011. (The regressions using the latter metric are therefore limited to credit agreements from 2013-2016, rather than from 2011-2016, in order to construct the two-year look-back for market share.) Because loan volume was exceptionally low in 2008 and 2009, we exclude those years in all calculations, instead looking back to the immediately preceding years where applicable.

22 The current ranking is available at

http://www.chambersandpartners.com/12788/6/editorial/5/1 (last visited on June 28, 2016). Unfortunately, the "Banking and Finance: Nationwide" category extends beyond syndicated loans, and does not distinguish between borrower-side and lender-side work.

${ }^{23}$ In the event that the borrower was represented by more than one law firm for the same loan (as where local-counsel opinions were sought regarding collateral, for example), the borrower is coded as having been represented by a top-ranked law firm if any of the borrower's law firms was top-ranked for that year. The borrower's law firm was not reported for 1,104 of the 4,164 loans in the sample. In each such instance, the borrower's law firm is coded as though it were not top-ranked, on the theory that it was not disclosed either because the law firm was relatively unknown or because the borrower relied solely on in-house counsel to negotiate the loan terms. As a robustness check, all observations for which the borrower's law firm was not reported were excluded from the sample in unreported regressions, which yielded similar results to those reported here.

24 In unreported regressions, similar results were obtained using top 10 and top 15 rankings as cutoffs. 


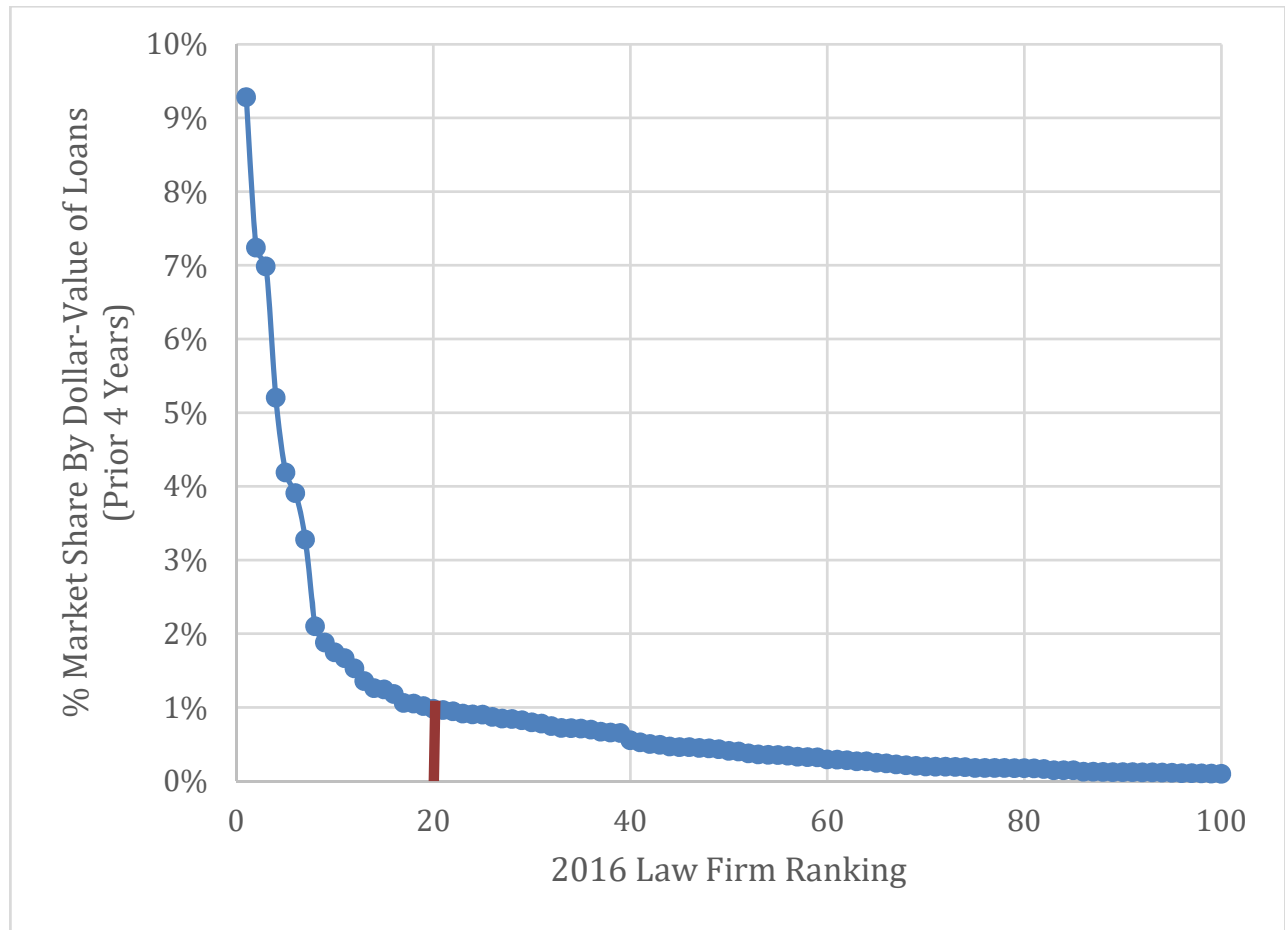

Table 1 below presents summary statistics for the 2,982 leveraged loans in the sample, which are used in the reported regressions. On average, private equity-backed loans in the sample are larger than non-sponsored loans and are more likely to have been (i) negotiated by a top-ranked law firm, (ii) secured, and (iii) incurred in connection with an acquisition.

Table 1. Summary Statistics.

Borrower Sponsored by

Private

Number
of Loans

Average Represented by

Equity Firm?

Sponsored

$(14.4 \%)$

Loan Size Top 20-Ranked

(in USD)

Law Firm (\%) ${ }^{25}$

Acquisition-

\$718 million

$59.0 \%$

$95.1 \%$

Related

2,553

$\$ 547$ million

$23.1 \%$

$72.0 \%$

$14.6 \%$

$(85.6 \%)$

Full sample

$$
2,982
$$

$\$ 572$ million

$28.3 \%$

$75.2 \%$

$16.3 \%$ $(100 \%)$ volumes.

${ }^{25}$ Figures reported here using rankings for the metric based on Bloomberg-reported loan 


\section{B. Model and Results}

A logit regression model is used here to test whether private-equity-owned borrowers are more likely than public companies to select top-ranked counsel for their syndicated loan transactions. The specification is as follows:

$$
\operatorname{logit}(\text { Top_Firm })=\alpha+\beta_{1} \times \text { Sponsored }+\beta_{2} \times X_{2}+\cdots+\beta_{N} \times X_{N}+\varepsilon
$$

where each loan transactions is a separate observation, the logit function is the natural logarithm of the odds ratio that the borrower will select top-ranked finance counsel for that loan, $\alpha$ and $\beta_{1}$ through $\beta_{\mathrm{N}}$ are the scalar constant and coefficients, respectively, to be estimated by the regression, Sponsored is an indicator variable identifying whether the borrower is private equitysponsored, and $\boldsymbol{X}_{2}$ through $\boldsymbol{X}_{\boldsymbol{N}}$ are control variables capturing loan characteristics that might affect the desirability of elite-quality counsel.

Specifically, the regression controls first for loan size, as we would expect larger loans to be associated with higher-quality counsel, all else equal. Acquisition-related loans might also call for higher-quality counsel, because the acquisition itself may involve significant regulatory and litigation risk, and contingencies associated with the acquisition increase the complexity of the loan transaction. ${ }^{26}$ Syndicated loans that are secured are also relatively more complex, thus potentially increasing the value to the borrower of more elite counsel. In addition, loans to borrowers in certain industries may present uniquely complex regulatory issues, thereby affecting choice of counsel. ${ }^{27}$

Finally, the debt markets recognize a significant divide between investment-grade debt and below-investment grade ("high-yield" or

26 See CORNERSTONE RESEARCH, SHAREHOLDER LitIGATION INVOLVING ACQUiSitions of Public Companies: Review of 2014 M\&A Litigation 1 (2015) (finding that 93 percent of all mergers and acquisitions transactions with targets valued over $\$ 100$ million resulted in litigation).

27 Under an adversarial model of transaction bargaining, one might also wish to control for the quality of the agent's counsel. The regressions reported herein do not do so, however, because there were too few observations for which the agent's counsel was reported. Further, in the syndicated-loan market, it is not uncommon for the agent's counsel to be selected only after the borrower's counsel has been selected, and, in many cases, subject to the borrower's approval. (Private equity firms in particular have been able to narrow the agent's choice to "designated lender counsel" that is hand-picked by the private equity firm.) Most importantly, financing transactions should not be thought of as adversarial, zero-sum, negotiations. In most cases, it is in the parties' interests to maximize their joint aggregate surplus from the transaction (such as by devising terms that lower the parties' collective transaction costs), prior to negotiating how that surplus should be split. See de Fontenay, supra note 7 . Given that, the relationship between the quality of borrower's counsel and the quality of lender's counsel need not be linear. 
"leveraged") debt in terms of risk, documentation, and creditors. ${ }^{28}$ Investment-grade loans commonly involve blue-chip borrowers and relatively simple credit agreements with few covenants and other restrictions affecting the borrower. Leveraged loans, by contrast, involve borrowers with a high proportion of debt in their capital structure (either by choice or as a result of financial distress), and are thus associated with complex credit agreements and highly restrictive covenants.

The predicted effect of investment-grade status on the borrower's choice of counsel is unclear, however. The simpler investment-grade deals might entail less incremental value to engaging higher-quality counsel, but investment-grade issuers may have a greater ability to pay for high-quality counsel on average. To address this distinction in the two types of syndicated loans, the regressions reported here are limited to leveraged loans (loans rated below investment-grade by the credit rating agencies), for a final sample size of 2,982 agreements. (Unreported regressions use the full sample of loans, but control for whether a loan is rated investment-grade.)

Table 2 presents the regression results for the leveraged-loan sample, with the three reported models differing only in the metric used to rank the law firms. First, there is a large, positive, and statistically significant association between the borrower's status as a private equity-sponsored company and the likelihood that the borrower will select elite-quality counsel. This result is robust to the use of the three different measures of law-firm quality. The odds that a borrower will be represented by a top-ranked law firm are approximately three to four times higher (depending on the ranking metric) if the borrower is private-equity-sponsored than if it is a public company. Second, among the control variables, the size of the loan and whether it is secured both significantly increase a borrower's likelihood of selecting elite counsel, while there was no statistically significant effect for whether the loan was issued in connection with an acquisition, or, in unreported regressions using the full sample, for whether the loan was investment-grade. Appendix A reports the results of the same regressions, with the addition of industry control variables. ${ }^{29}$

28 See STANDARD \& POOR's, A GuIDE TO THE LOAN MARKET 7, 13, 23 (2012), available at https://www.lcdcomps.com/d/pdf/LoanMarketguide.pdf.

${ }^{29}$ Regression models with fixed effects for the year in which the loan was issued did not generally produce statistically significant results for the year indicators and are omitted here. 
Table 2. Logistic Regression Results: Effect of Private Equity-Ownership on Borrower's Odds of Selecting Elite Counsel.

\begin{tabular}{lccc}
\hline & Top-Firm_1 & Top-Firm_2 & Top-Firm_3 \\
\hline Sponsored & 4.184 & 2.925 & 3.747 \\
& $(12.51)^{* *}$ & $(7.79)^{* *}$ & $(11.47)^{* *}$ \\
$\ln$ (Loan Amount) & 1.557 & 1.537 & 1.706 \\
& $(10.59)^{* *}$ & $(8.75)^{* *}$ & $(12.42)^{* *}$ \\
Acquisition Purpose & 1.066 & 1.041 & 1.000 \\
& $(0.56)$ & $(0.30)$ & $(0.00)$ \\
Secured Loan & 1.882 & 1.536 & 1.711 \\
& $(5.61)^{* *}$ & $(3.38)^{* *}$ & $(4.75)^{* *}$ \\
$\mathbf{N}$ & & & $\mathbf{2 , 9 8 2}$ \\
\hline
\end{tabular}

* Significant at the $5 \%$ level $(\mathrm{p}<0.05)$

$* *$ Significant at the $1 \%$ level $(\mathrm{p}<0.01)$

Note: The reported logistic regression coefficients are odds ratios. Z statistics are in parentheses.

Table 3. Variable Definitions.

Variable Definition

Dependent Variable:

Top-Firm_1 Equal to 1 if the borrower's law firm was among the top 20 borrower-side law firms for the year in which the loan was issued, ranked according to aggregate market share of borrower-side representation for leveraged loans over the previous four years (excepting 2008-2009), using leveraged loan volumes by law firm reported by Bloomberg. The sample period for this model is 2011-2016.

Top-Firm_2 Equal to 1 if the borrower's law firm was among the top 20 borrower-side law firms for the year in which the loan was issued, ranked according to aggregate market share of borrower-side representation for leveraged loans over the previous two years, using leveraged loan volumes by law firm from within the sample (Practical Law). The sample period for this model is $2013-2016$.

Top-Firm_3 Equal to 1 if the borrower's law firm was listed in any tier of the Chambers and Partners "Banking \& Finance: Nationwide" rankings in the prior year. The sample period for this model is 2011-2016. 
Independent Variables:
Sponsored
Equal to 1 if the borrower was private equity-owned when the loan transaction closed.
Ln(Loan Amount) Natural logarithm of the principal amount of the loan facility in U.S. dollars.
Acquisition Purpose Equal to 1 if the loan was issued at least in part to finance an acquisition.
Secured Loan
Equal to 1 if any part of the loan was secured by the borrower's assets.

\section{INTERPRETING THE RESULTS}

Controlling for loan characteristics, then, public companies appear to select lower-ranked counsel for their bank-debt financings than do privateequity-owned companies. ${ }^{30}$ Before proceeding, however, a clarification is in order as to who selects outside counsel for each group. The regression sample consists of large U.S. syndicated loans by private-equity-sponsored companies and (non-sponsored) public companies. Thus, in the former case, the regression estimates the quality of financing counsel engaged by private equityowned companies (the "portfolio companies"), rather than by the private equity sponsors (the investment professionals) or the private equity funds (the investment vehicles) themselves. The goal is to obtain a sample of organizations (in this case, large operating companies) of comparable size and other characteristics. Yet for large financing transactions such as those covered by the sample, borrower's counsel is, in practice, selected by the private equity sponsor, rather than by the portfolio company itself, even though the latter bears the debt. ${ }^{31}$ In the case of public companies, borrower's counsel is typically selected by the company's general counsel (if any), ${ }^{32}$ subject in some cases to management-imposed restrictions discussed in Part II.B. As we will see, this difference in decision-making agency between the two groups may explain much of the discrepancy in the quality of counsel that they select.

30 Anecdotal evidence also suggests that private equity sponsors hire top-tier law firms when acquiring companies, while the target companies (often public companies) do so less often. See Steven M. Davidoff, The Failure of Private Equity, 82 S. CAL. L. REv. 481, 534-38 (2009).

31 See id.

32 See, e.g., Abram Chayes \& Antonia H. Chayes, Corporate Counsel and the Elite Law Firm, 37 StAn. L. REV. 277, 277-78 (1985); Deborah A. DeMott, The Discrete Roles of General Counsel, 74 FORDHAM L. REV. 955, 960, 971 (2005). 


\section{A. The Private Equity Perspective}

Returning to the regression results, what factors explain the two groups' differing choices of counsel, and what, if anything, can be said about whether these choices are value-maximizing? Somewhat surprisingly, the latter question is the easier to address, and we begin there. Even before identifying what drives their choice of counsel, we have good reasons to believe that private equity firms act relatively efficiently in favoring elite counsel for their financing transactions.

First, the stakes are generally higher for private equity firms than for public companies. Private equity-owned companies are, on average, significantly more leveraged than their public-company counterparts. ${ }^{33}$ Any marginal increase in transaction value that an elite law firm can provide represents, on average, a greater overall economic advantage for a private equity-owned company than it would for a comparably-sized public company. Simply put, private equity-owned companies will, on average, get more bang for their buck from an improvement in financing terms than would a comparable public company.

Second, we should expect private equity firms to internalize the costs and benefits of their portfolio companies' legal representation relatively well, meaning that the economic effects of choice of counsel flow through to the party that ultimately makes that choice. Indeed, as the sole or majority shareholder of its portfolio companies, a private equity fund's interests are largely aligned with those of its portfolio companies. ${ }^{34}$ Moving up the ladder, the typical compensation structure-which provides for a twenty-percent carried interest - ensures that the private equity firm (sponsor) itself is highly motivated to increase portfolio companies' value. ${ }^{35}$ In turn, the carried interest is typically shared among a relatively small number of individuals. ${ }^{36}$ The

33 See Ulf Axelson, Tim Jenkinson, Per Strömberg, \& Michael S. Weisbach, Borrow Cheap, Buy High? The Determinants of Leverage and Pricing in Buyouts, 68 J. FIN. 2223, 2239 (2013).

${ }^{34}$ But see Gretchen Morgenson, When Private Equity Firms Give Retirees the Short End, N.Y. TIMES, June 13, 2015, available at

http://www.nytimes.com/2015/06/14/business/retirement/when-private-equity-firms-giveretirees-the-short-end.html? $\mathrm{r}=0$ (discussing examples of private equity firms receiving discounts from law firms on legal work pertaining to the firm itself, while their fund investors are charged premium rates by the same firms for transactional work). Such volume discounts for the private equity firm, rather than the fund, could incentivize private equity firms to select higher-quality law firms for the fund work than would be optimal. In October 2015, Blackstone, a major private equity sponsor, reached a settlement with the SEC for its alleged failure to disclose such a differential fee structure negotiated with its law firm.

35 See Steven N. Kaplan \& Per Strömberg, Leveraged Buyouts and Private Equity, 23 J. ECON. PERSP. 121, 124 (2009).

36 See id. at 123 (noting that even the largest private equity firms are "still small relative to the firms in which they invest."); Michael C. Jensen, Eclipse of the Public Corporation, HARV. Bus. 
private equity ownership and compensation structure thus maintains relatively high-powered incentives for the individuals responsible for affecting firm value, in contrast to the diffuse management incentive problems that plague large public companies.

Third, private equity firms are sophisticated, high-volume players for this type of loan transaction. If elite law firms do indeed increase the value of their loan transactions, then private equity firms are particularly well poised to recognize and to capitalize on this advantage.

In sum, we have good reasons to believe that private equity firms perform relatively well at maximizing value through their selection of counsel, though the data presented herein cannot resolve the question. Private equity firms' preference for higher-ranked law firms therefore suggests that such firms provide them, on average, with a better economic deal-even taking into account higher legal fees. Equivalently, private equity firms are unlikely to be simply overpaying for legal services. Their preference for higher-ranked firms thus provides a benchmark for evaluating the selection of counsel by public companies, the task to which we now turn.

\section{B. Is The Private Equity Calculus Generalizable?}

If we accept the premise that private equity firms select the quality of their counsel relatively efficiently, we are left with two alternative hypotheses for the finding that public companies opt for lower-ranked financing counsel:

1) High-quality law firms benefit private-equity-owned companies more than they do public companies, all else being equal; or

2) High-quality law firms benefit private equity-owned companies and public companies equally, but public companies choose lower-ranked firms for non-value-maximizing reasons.

This section discusses the first hypothesis, while the second is addressed in Part $\mathrm{C}$ below. There are two principal reasons why elite counsel might, on average, benefit private equity firms more than another types of corporate clients. First, private equity firms' raison d'être is to acquire portfolio companies and to dispose of them at a premium. They are therefore involved in mergers and acquisitions $(M \& A)$ activity far more frequently than are public companies, on average. Because private equity M\&A is leveraged, each of these acquisition transactions is typically accompanied by a simultaneous debt financing transaction. Thus, to the extent that private equity firms select elite counsel for their financing transactions, this may simply be a reflection of their

REV., Sept.-Oct. 1989, at 70. 
antecedent need for elite M\&A counsel. ${ }^{37}$ Indeed, large M\&A transactions often involve complex regulatory concerns (such as antitrust and securities regulation), litigation risk (shareholder lawsuits and appraisal proceedings), and tactical maneuvering (such as takeover defenses and auction processes), for which an experienced law firm proves invaluable. ${ }^{38}$

The regression model seeks to minimize the potentially distorting influence of M\&A by controlling for whether a loan was issued in connection with an acquisition. (Interestingly, the latter had no statistically significant effect on the borrower's likelihood of choosing top-ranked counsel in our results.) This does not fully address the problem, however. Imagine, for example, that a private equity firm hires an elite firm for its acquisition of a particular target company and the accompanying financing. If the target-now a portfolio company-later opts to refinance its debt, the new debt is no longer coded as acquisition-related. Nonetheless, the initial choice of elite counsel for the acquisition likely increases the probability that elite counsel will be used for the refinancing: clearly there are economies of scale in using the same law firm for a given company's subsequent financings. Thus, even controlling for acquisition-related loans, private equity-owned companies may be more likely to select elite counsel for their financings than companies starting from a clean slate.

A second potential explanation for why elite counsel might benefit private equity-sponsored companies and public companies differentially might be that, contrary to a key assumption of the regression model, loans to the two groups effectively amount to two different legal products. Thus, for example, the added complexity of private-equity-related financings (as compared to "plain vanilla" public-company loans) may be sufficiently large that elite counsel simply adds more value, all else being equal. The financing contingencies associated with leveraged acquisitions create additional risks for creditors and complicate both the structuring and the documentation. In order to minimize heterogeneity in the sample from legal complexity, the regression model controls for whether a loan is acquisition-related, secured, or (in unreported regressions) investment-grade. While such controls are designed to achieve better matching in the sample, they may nonetheless be imperfect or insufficient correctives. ${ }^{39}$

37 See Davidoff, supra note 25.

38 See C.N.V. Krishnan \& Ronald W. Masulis, Law Firm Expertise and Merger and Acquisition Outcomes, 56 J.L. \& ECON. 189, 192 (2013) (finding an association between the use of top-tier law firms in M\&A transactions and better client outcomes).

39 Notwithstanding, simply pointing to the fact that private-equity-sponsored loans tend to involve more complex terms does not on its own entail that such loans should be treated as a different class of legal work from public-company loans: the effect may be at least partly endogenous, reflecting the influence of more elite counsel for private equity deals. 


\section{The Public Company Perspective}

This section assumes that elite counsel does on average add more value to all clients' loan transactions than lower-ranked counsel, and identifies possible explanations for why public companies are nonetheless less likely than private equity firms to employ elite counsel. ${ }^{40}$ If private equity firms are correct, hiring a lower-ranked firm is inefficient-tantamount to passing up free money. How, then, do we account for the choice made by public companies?

\section{General Counsel Decision-Making.}

One approach is to hypothesize a variety of inefficiencies in the demand for legal services by public companies. First, public companies may select their outside counsel sub-optimally due to a pure information problem, preventing them from accurately gauging law firms' quality or the relationship between law firm quality and transaction value. Certainly some degree of information asymmetry exists between companies and law firms as the former contract for legal services. ${ }^{41}$ A prime example of credence goods, ${ }^{42}$ legal services are notoriously difficult to value. Specifically, if the general counsels of public companies are unsophisticated or inexperienced at weighing the costs and benefits of outside counsel services, they may well select their counsel poorly. Perhaps general counsels, often far removed from their days in private practice, underestimate the value of top-ranked firms' services, and law firms are unable to convey these benefits convincingly. Similarly, general counsels

40 The finding that public companies are incentivized to pick lower-quality firms than is optimal stands in contrast to the oft-told story that companies hire prestigious firms as cover for their own decisions or actions. See, e.g., Brian Uzzi et al., Your Client Relationships and Reputation: Weighing the Worth of Social Ties: Embeddedness and the Price of Legal Services in the Large Law Firm Market, in MANAging THE Modern LAw Firm: New Challenges, NeW Perspectives 91, 115 (Laura Empson ed., 2007) (concluding that "in-house counsel...use [law-firm] status to justify a hiring decision to their superiors or to cover themselves in case something goes wrong with the deal even though a lower cost firm of equal quality is available."). The difference may turn on the degree of risk and visibility involved: for low-risk transactions such as a routine loan financing-even a very large one-general counsels may spend too little on their law firms, consistent with this Article's findings. For high-risk, highvisibility transactions, by contrast, general counsels may be personally incentivized to have the company overspend on law-firm quality. See also Deborah A. DeMott, The Stages of Scandal and the Roles of General Counsel, 2012 Wis. L. Rev. 463 (2012) (discussing the interrelationship between the reputations of the general counsel and the corporation it serves).

41 See John C. Coates IV, Explaining Variation in Takeover Defenses: Blame the Lawyers, 89 CAL. L. REV. 1301, 1310 (2001) ("[P] rincipals (clients) have little information about what their agents are doing”); RICHARD SUSSKIND, THE END OF LAWYERS? RETHINKING THE NATURE OF LEGAL SERVICES 148-49 (2008) (noting how the incentives of law firms and their clients may diverge).

42 See Michael R. Darby \& Edi Karni, Free Competition and the Optimal Amount of Fraud, 16 J.L. \& ECON. 67, 67 (1973) (defining credence goods). 
may be overly confident in their in-house staff's abilities and therefore spend too little on outside counsel.

As far as it goes, this argument seems unsatisfactory. The general counsels of the largest public companies are often taken directly from elite law firms, and thus could hardly be described as unsophisticated about the work performed by such firms. Further, it is unclear why a lack of sophistication would result in a systematic preference for lower-ranked counsel. Indeed, plausible arguments exist for the opposite result, with unsophisticated general counsels biased in favor of higher-ranked counsel: precisely because they lack information, unsophisticated general counsels might be most likely to rely on rankings as the best proxy for quality and to seek the highest-ranked counsel.

A more promising set of explanations derives from a second type of inefficiency in the demand for legal services, namely the agency costs associated with public-company general counsels. Assume here that a general counsel is well aware that spending more on a law firm should be expected to result in a better economic deal for the company, even net of legal fees. Nonetheless, she proceeds to staff the transaction either with a less expensive law firm or with the company's in-house lawyers. While this choice is suboptimal from the perspective of the company's shareholders, it may nonetheless advance the general counsel's private interests. Certainly the general counsel has at least some incentive to maximize the corporation's value, whether for self-interested reasons (such as increasing the value of her stock options and ensuring her continued employment) or simply acting as a faithful agent of the company. Yet the general counsel's private incentives also include concerns such as pleasing management and maximizing the visibility and prestige of the in-house counsel team within the company. ${ }^{43}$

Thus, general counsels may tend to favor in-house counsel over outside counsel or to hire cheaper outside counsel for a transaction for several reasons. First, once in-house staff has been hired, the general counsel has strong incentives to see it utilized to capacity and even expanded: steering transactional work to in-house lawyers reduces the unpleasant prospect of staff layoffs and increases their visibility and influence with the rest of the management team. ${ }^{44}$ As the company's chief legal officer and the person responsible for hiring and overseeing in-house counsel, the general counsel may well view his key task-second only to avoiding catastrophic legal risk for the company - as justifying, on a daily basis, the existence of the in-house legal team.

Second, as a mechanism to limit discretionary spending, within many companies the board of directors or upper-level management must approve-

\footnotetext{
43 See, e.g., Donald C. Langevoort, Getting (Too) Comfortable: In-house Lawyers, Enterprise Risk, and the Financial Crisis, 2012 WIS. L. REV. 495 (2012)

44 See David Wilkins, Teams of Rivals: Toward a New Model of the Corporate Attorney/Client Relationship, in CURRent LeGal Problems 2009669 (2010).
} 
formally or informally — the general counsel's decision to hire outside counsel. Similarly, many general counsels are restricted to selecting from among a preapproved, short list of law firms for the company's legal work. ${ }^{45}$ Absent express permission from the board, this prevents a general counsel from engaging a different firm for a transaction on a one-off basis, even if-in his view-it would be the best firm for the job. Such approval requirements should lead general counsels to spend less on outside counsel than is optimal: they may be reluctant to expend their political capital within the company on a decision that only provides them with highly attenuated private benefits.

In simple cost-benefit terms, the costs to the company of hiring elite counsel are immediate, tangible, and incurred with certainty, while the benefits of doing so are typically delayed, intangible, uncertain, and impossible to measure precisely even after the fact. ${ }^{46}$ Persuading her company to engage more expensive counsel may thus prove difficult for a general counsel, even if she truly believes that the benefits outweigh the costs. Indeed, whereas the inhouse legal department effectively amounts to a fixed (and sunk) cost, legal fees for outside counsel represent an additional, highly visible cash outlay. ${ }^{47}$ At the same time, the board and senior management are poorly positioned to appreciate the benefits of better counsel. Such benefits cannot be measured in any particular instance: the output of a law firm's efforts is largely intangibleit is difficult to ascribe a cash value to having a particular covenant in a loan agreement, for example-and even were that not the case, measuring the added economic benefit of a higher quality law firm requires a calculation based on an unknowable counterfactual scenario, namely what transaction value a lower-quality firm would have produced on behalf of the client. Finally, even if we expect that, on average, paying more for an elite law firm will result in a greater transaction value expost, there is no assurance ex ante that this will be the case. (Stated differently, while the expected transaction value should be higher with a higher-ranked law firm, the actual, realized value need not be: there is some risk involved.) A risk-averse general counsel might thus prefer less expensive counsel, in order to avoid shouldering the blame vis-à-vis the rest of the management team if the costs ultimately end up outweighing the benefits. ${ }^{48}$ All told, the general counsel's private cost-benefit calculus may, at the margins, lead her to take the path of least resistance (and risk) and opt (2001).

45 See, e.g., Larry Smith, Inside/Outside: How Businesses Buy LeGal Services 173

46 See Coates, supra note 36, at 1311-13 (summarizing the difficulties in assessing the costs and benefits of legal advice in the context of initial public offerings).

47 See, e.g. Jonathan T. Molot, What's Wrong with Law Firms? A Corporate Finance Solution to Law Firm Short-Termism, 88 S. CAL. L. REV. 1 (2014) (noting that "institutional clients have begun to wonder whether they should use less prestigious, lower-cost firms...”).

48 As discussed, in other settings (such as high-stakes litigation or a hostile acquisition), general counsel risk aversion might tilt in favor of engaging more expensive counsel. See Uzzi et al., supra note 35 at 115. 
for less expensive counsel.

All this to say that, due to agency and influence costs, the general counsels of large public companies arguably internalize the costs and benefits of their companies' choice of transactional counsel less than do private equity firms, and that, consistent with our empirical results, this can prompt them to underspend on outside counsel. ${ }^{49}$ Public-company general counsels act within large, bureaucratic organizations, and have conflicting allegiances to shareholders, management, and their in-house staff. Large corporations are by all accounts intensely political environments, and we should not be surprised that, like all other corporate management positions, the general counsel role engenders agency and influence costs. ${ }^{50}$ In this particular case, it may lead general counsels to make suboptimal decisions in selecting counsel for major transactions.

\section{Relationship Lawyering 2.0?}

An alternative, and less troubling, explanation for the discrepancy between the law firms chosen by private equity-owned companies and public companies deserves mention. "Relationship lawyering" refers to corporate clients' practice of directing virtually all of their legal work to a single law firm (or a very small number of law firms), over a long period of time. Commentators have noted (and often decried) the contemporary decline of relationship lawyering for corporate clients, ${ }^{51}$ with a client's long-term relationship with a single firm being replaced by one-off, impersonal engagements with numerous firms. ${ }^{52}$ Yet decline does not equate to

${ }^{49}$ While large private equity firms are likely to have general counsels themselves, their inhouse staff (if any) is negligible in size compared to that of large public companies, as the private equity compensation scheme provides incentives to keep staffing to a barebones minimum. Further, they face significantly higher-powered incentives than their counterparts at public companies, thus benefitting more from any given increase in firm value. They are thus significantly less likely to suffer from the agency and influence costs of public-company in-house legal departments.

50 The seminal treatment of intra-firm agency costs and influence costs is from Williamson (1991) and Milgrom and Roberts (1990), respectively. See Paul Milgrom \& John Roberts, Bargaining Costs, Influence Costs, and the Organization of Economic Activity, in PERSPECTIVES On Positive Political Economy 58 (James E. Alt \& Kenneth A. Shepsle eds., 1990) (defining "influence costs" as the costs of political activity within firms); Oliver E. Williamson, The Limits of Firms: Incentive and Bureaucratic Features, in THE ECONOMIC INSTITUTIONS OF CAPITALISM (1985).

See also Geoffrey Miller \& Gerald Rosenfeld, Intellectual Hazard: How Conceptual Biases in Complex Organizations Contributed to the Crisis of 2008, 33 HARV. J.L. \& PUB. POL'Y 807 (2010).

51 See generally Ronald J. Gilson, The Devolution of the Legal Profession: A Demand Side Perspective, 49 MD. L. REV. 869 (1990); Robert Eli Rosen, "We're All Consultants Now": How Change in Client Organizational Strategies Influences Change in the Organization of Corporate Legal Services, 44 ARIZ. L. REV. 637 (2002).

52 See, e.g., Gillian K. Hadfield, Legal Infrastructure and the New Economy, 8 I/S: J.L. \& 
disappearance. Under certain conditions, using a relationship firm (or, as may be more common today, two or three relationship firms) for a corporate transaction may be the optimal choice for a company, even if the relationship firm is relatively less experienced with that type of transaction. ${ }^{53}$ Even assuming that an elite firm with significant transactional experience might, for example, obtain better deal terms for the company, the cost savings from using its relationship firm could conceivably outweigh this. This would be due not simply to the relationship firm's lower fees, but more importantly to its familiarity with the company's unique regulatory issues and its ready access to information within the company. Indeed, the traditional justification for relationship lawyering is the greater (and less costly) information flow between client and law firm, relative to one-off engagements, resulting in lower transaction costs. ${ }^{54}$

Thus, while we can posit that a large public company is likely to do better on a financing transaction using an elite firm rather than a lower-ranked firm on a one-off basis, the same is not necessarily true if the comparison is between using an elite firm on a one-off basis and using a lower-ranked relationship firm. Ironically, in fact, private equity firms themselves can be considered champions of the relationship-firm model, in a sense. Most of the largest private equity firms direct the bulk of their business to one or two law firms. ${ }^{55}$ However, much of this has to do with such firms' long-standing experience with, and market knowledge of, M\&A and financing transactions. Simply put, the relationship firms of the largest private equity sponsors are the most elite law firms ${ }^{56}$ making it difficult to parse the specific sources of value that they provide. Finally, there is another key distinction to be drawn between relationship lawyering involving private equity firms and public operating companies. While public companies' relationship law firms are familiar with the operating companies themselves, in the private equity context the

POL'Y FOR INFO. SOC’Y 1, 33 (2012) (finding that companies have begun spreading legal work across a greater number of law firms); David B. Wilkins, Is the In-House Counsel Movement Going Global? A Preliminary Assessment of the Role of Internal Counsel in Emerging Economies, 2012 WIS. L. REV. 251, 258 (2012) (noting general counsels' ability to make several law firms compete for business).

53 See John C. Coates et al., Hiring Teams, Firms and Lawyers: Evidence of the Evolving Relationships in the Corporate Legal Market, 36 L. \& SOC. INQUIRY 999 (2011) (finding that, while large corporations today use several law firms, their relationships with such firms tend to persist over time); David B. Wilkins, Team of Rivals? Toward a New Model of the Corporate Attorney-Client Relationship, 78 Fordham L. Rev. 2067, 2070 (2010) (describing a new stage in the evolution of law firm/client relations, moving from impersonal, one-off spotcontracting to something akin to strategic partnerships).

54 See Gilson, supra note 46.

55 See Steven M. Davidoff, The Failure of Private Equity, 82 S. CAL. L. REV. 481, 535-37 (2009) (describing the persistent relationships between large private equity firms and a small set of elite law firms).

56 see id. 
relationship law firms are familiar with the private equity firm, but not necessarily with the portfolio companies that they acquire. ${ }^{57}$ The informational efficiencies from the law firm/client relationship should therefore differ in kind, further complicating the comparison.

In short, if the agency-cost account is correct, public companies are likely under-spending on legal counsel for their major corporate transactions, and thus forgoing better economic outcomes. If instead the relationship-lawyering account is the correct one, then the discrepancy in law firm usage between private equity firms and public companies may be relatively benign or even efficient. Private equity firms get the benefit of better deal terms by hiring top-tier, repeat-player law firms, while public companies may, in some cases, maximize their transaction surplus by sticking with their lower-ranked relationship law firm(s), which reduces information costs. ${ }^{58}$

The answer depends on how skilled public companies are at weighing the costs and benefits of never defecting from their relationship firms, and this Article's empirical results alone do not provide the answer. For the reasons discussed above, however, we might suspect that public companies tend to place too much emphasis on transaction costs, due to their greater salience, while discounting the true benefits of higher-quality law firms. We should be particularly skeptical of companies' attempts to lower out-of-pocket costs for the very largest transactions, for which transaction costs are, on a relative basis, less significant. ${ }^{59}$ Thus, there is reason to doubt whether companies that employ their lower-ranked relationship firms for major transactions areabsent truly significant, company-specific risks-correctly balancing the associated costs and benefits.

\section{Case Study: A Tale of Four Financings}

Specific examples starkly illustrate the divergence in legal representation between private-equity-sponsored and (non-sponsored) public companies identified in the regression results from Part I. Table 4 below provides a (non-

\footnotetext{
${ }^{57}$ For many reasons, it is usually infeasible for private equity firms to engage law firms that are already very familiar with their portfolio companies. For example, if a private equity firm is seeking to make an acquisition, then the target corporation's long-standing counsel would either be representing the seller or would be conflicted in the transaction, and the seller would have little incentive to waive the conflict.

${ }^{58}$ Of course, we are left with the question of why public companies appear to have lowerranked relationship law firms than do private equity sponsors. The most plausible answer is that large, public operating companies are more likely than private equity firms to generate routine legal work (such as negotiating commercial contract forms or litigating employment disputes) for which the cost of elite-quality counsel is not justified.

59 See Schwarcz, supra note 13, at 507 (noting that for large transactions, "legal fees are relatively small compared to overall transaction costs and benefits.”).
} 
exhaustive) list of multi-billion-dollar syndicated loans for which major public corporations chose to be represented by law firms falling outside the elite circle of U.S. borrower-side finance counsel.

Table 4. Public Company Legal Representation for Syndicated Loans.

\section{Borrower}

Reynolds American Inc.

Lockheed Martin Corporation

Duke Energy Corporation

McKesson Corporation

Halliburton Company

Constellation Brands, Inc.

Fidelity National Information Services

MetLife, Inc.

National Oilwell Varco, Inc.

Philip Morris International Inc.

Apache Corporation

Noble Energy, Inc.

Hologic, Inc.

ARRIS Group, Inc.

Universal Health Services, Inc.

Air Lease Corporation

American Airlines, Inc.

Jabil Circuit, Inc.

CenturyLink, Inc.

QVC, Inc.

United Air Lines, Inc.

PPG Industries, Inc.

Lowe's Companies, Inc.

Iron Mountain Incorporated

Supervalu Inc.

Steel Dynamics, Inc.

Patterson Companies, Inc.

PTC Inc.

Intuit Inc.

Northrop Grumman Corporation

\begin{tabular}{|c|c|}
\hline Loan Size & $\underline{\text { Year }}$ \\
\hline$\$ 9$ billion & \\
\hline$\$ 7$ billion & \\
\hline$\$ 6$ billion & \\
\hline$\$ 5.5$ billion & \\
\hline$\$ 4.5$ billion & 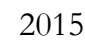 \\
\hline$\$ 4.4$ billion & \\
\hline$\$ 4$ billion & \\
\hline$\$ 4$ billion & \\
\hline$\$ 3.5$ billion & \\
\hline$\$ 3.5$ billion & \\
\hline$\$ 3.5$ billion & 2 \\
\hline$\$ 3$ billion & 201 \\
\hline$\$ 2.8$ billion & \\
\hline$\$ 2.8$ billion & 20 \\
\hline$\$ 2.6$ billion & \\
\hline$\$ 2.1$ billion & \\
\hline$\$ 2.1$ billion & 201 \\
\hline$\$ 2$ billion & \\
\hline$\$ 2$ billion & \\
\hline$\$ 2$ billion & \\
\hline$\$ 1.9$ billion & \\
\hline$\$ 1.8$ billion & \\
\hline$\$ 1.75$ billion & \\
\hline$\$ 1.75$ billion & \\
\hline$\$ 1.7$ billion & \\
\hline$\$ 1.5$ billion & 20 \\
\hline$\$ 1.5$ billion & \\
\hline$\$ 1.5$ billion & \\
\hline$\$ 1.5$ billion & \\
\hline$\$ 1.5$ billion & \\
\hline
\end{tabular}

\section{Borrower Law Firm}

Kilpatrick Townsend \& Stockton LLP

Hogan Lovells US LLP

Robinson, Bradshaw \& Hinson, P.A.

Morrison \& Forester LLP

Baker Botts L.L.P.

Nixon Peabody LLP

Nelson Mullins Riley \& Scarborough LLP

Willkie Farr \& Gallagher LLP

Haynes and Boone, LLP

Hunton \& Williams LLP

Porter \& Hedges, LLP

Thompson \& Knight L.L.P.

Brown Rudnick LLP

Troutman Sanders LLP

Fulbright \& Jaworski L.L.P.

Manatt, Phelps \& Phillips, LLP

Pillsbury Winthrop Shaw \& Pittman LLP

Holland \& Knight LLP

Jones, Walker, Waechter, Poitevent,

Carrère \& Denègre LLP

Sherman \& Howard L.L.C.

Hughes Hubbard \& Reed LLP

K\&L Gates LLP

Moore \& Van Allen PLLC

Sullivan \& Worcester LLP

Dorsey \& Whitney LLP

Barrett \& McNagny, LLP

Briggs and Morgan, P.A.

Edwards Wildman Palmer LLP

Fenwick \& West LLP

Sheppard, Mullin, Richter \& Hampton LLP

This Part III examines the various theories of how public companies select counsel in practice, using a brief case study. Specifically, it explores the decision by four major U.S. public companies to select un-ranked borrower's 
counsel for the loan transactions listed in Table 4 above. Each involved a loan facility exceeding a billion dollars, such that the economic impact of the actual loan terms was very high, while the cost of transaction counsel would have been relatively insignificant. This has two implications. First, with loans of that size, any incremental improvement in transaction value that counsel could provide would very likely outweigh the additional cost of elite firms. ${ }^{60}$ In other words, better counsel should, in expectation, pay for itself. Second, we can safely assume that these companies had the ability to pay for any counsel of their choosing. ${ }^{61}$ Therefore, in examining these companies' decision to opt for relatively lower-ranked counsel, the appropriate inquiry is limited to whether the expected economic loss in transaction value was offset by some other plausible benefit from their choice of counsel.

\section{A. Berkshire Hathaway}

With a market capitalization of nearly $\$ 350$ billion and an astonishing record of beating the U.S. stock market's performance over a fifty-year period, Berkshire Hathaway has long been a company of superlatives. As the third largest public company in the United States, however, Berkshire's spending on professional services is far from lavish. For its $\$ 8$ billion borrowing in November 2009-used to finance Berkshire's acquisition of Burlington Northern Santa Fe Corporation-the conglomerate selected as its counsel Munger, Tolles \& Olson LLP ${ }^{62}$ a comparatively small though highly-regarded law firm. ${ }^{63}$ The connection between Berkshire and Munger Tolles is no accident: Charlie Munger, the legendary Berkshire director with a near fortyyear tenure, was one of the founders of Munger Tolles in 1962. ${ }^{64}$

Nonetheless, the decision to use Munger Tolles for such a large financing is far from self-evident, even putting aside the law firm's moderate size. Munger Tolles is primarily known for its elite litigation practice, rather than for

60 See id. (noting that transaction costs are less important for larger transactions).

${ }^{61}$ A common problem with analyses of consumers' revealed preferences is the difficulty of disentangling ability and willingness to pay for a particular good. In the case studies herein, there were no meaningful constraints on ability to pay for counsel, given the size of the corporations at issue.

62 See \$8,000,000,000 Credit Agreement Among Berkshire Hathaway Inc., The Lenders Party Thereto, and JPMorgan Chase Bank, N.A. (Nov. 18, 2009), available at http://www.sec.gov/Archives/edgar/data/934612/000119312509238536/dex3.htm.

63 The firm has approximately 200 attorneys across all of its offices.

${ }^{64}$ See Berkshire Hathaway Inc., Proxy Statement (May 2, 2015) (hereinafter "Berkshire Proxy Statement"), available at http://www.sec.gov/Archives/edgar/data/1067983/000119312515091378/d854690ddef14a. $\underline{\mathrm{htm}}$. Ronald Olson, also a Berkshire director (since 1997), is another founder of Munger Tolles and remains a partner of the firm to this day. Id. 
transactional work. ${ }^{65}$ More to the point, while Munger Tolles can credibly claim to offer highly sophisticated, bespoke service to its clients, it cannot claim to have the same grasp of the "market" terms of large loan transactions as the elite, (generally) New York-based, law firms that dominate the syndicated-loan market-nor the same experience drafting and negotiating them. Compared to such firms, Munger Tolles has a decidedly low-volume, low-market-share loan practice. Yet for an $\$ 8$ billion deal, the additional transaction costs (if any) involved in hiring a high-market-share firm over Munger Tolles would be truly negligible.

How, then, can we account for Berkshire's choice of firm in this instance? One possibility is that it reflected one or more conflicts of interest. Two of the law firm's founders, Charlie Munger and Ronald Olson, are currently directors of Berkshire Hathaway, with tenures of nearly forty and twenty years, respectively. ${ }^{66}$ While Charlie Munger is no longer associated with the law firm, Ronald Olson is still a practicing partner. Berkshire's decision to stick with Munger Tolles for its transactional work might thus be an example of modest cronyism, though there is no evidence that this is indeed the case.

A far more promising explanation is to point to the unusual culture of Berkshire Hathaway, which puts a significant premium on handling matters internally and with barebones staffing. Its longstanding CEO, Warren Buffett, is strikingly and vocally averse to intermediation. ${ }^{67}$ Though his disdain is primarily directed at investment banks, ${ }^{68}$ it arguably extends to law firms on the same principle, driving him to rely minimally on counsel by opting for a relatively small firm. The question, of course, is whether this strategy is ultimately beneficial to the company. If Berkshire's decision to eschew investment banks, for example, actually leads its potential acquisition targets to do the same, the company might reap significant benefits by acquiring companies at a significantly lower share premium than it otherwise would. ${ }^{69}$ It seems unlikely that opting for less-experienced financing counsel could reap similar benefits for the company, however. Moreover, the benefit of hiring experienced counsel would seem particularly important in this case, given that

\footnotetext{
65 See http://www.chambersandpartners.com/12059/717/editorial/5/1\#org 3535.

66 See Berkshire Proxy Statement, supra note 60.

67 See Lawrence A. Cunningham, Berkshire versus KKR: Intermediary Influence and Competition, 82 U. CHI. L. ReV. Dialogue 101 (2015).

68 See Berkshire Hathaway Inc., 2014 Letter to Shareholders, available at http://www.berkshirehathaway.com/letters/2014ltr.pdf.

69 See Neil Irwin, Why Warren Buffett Is Worth $\$ 72$ Billion and You're Not, N.Y. TIMES (March 2, 2105), available at http://www.nytimes.com/2015/03/03/upshot/why-warren-buffett-isworth-72-billion-and-youre-not-two-theories-on-berkshire-hathaway.html. The benefit to Berkshire comes not from the transaction-cost savings of avoiding investment banks, but from the fact that, without an investment bank to represent it, the target company is likely to be sold for a lower price.
} 
Berkshire almost never issues debt ${ }^{70}$ and therefore has little internal experience with the full range of contractual terms on which such financing can be obtained.

While Berkshire may be correct to be suspicious of the incentives of intermediaries in general, adhering to that principle in every instance betrays a near-ideological aversion to transaction costs that may not be valuemaximizing for each individual transaction. Perhaps, then, Berkshire's choice of counsel is best viewed as part of its broad strategies of signaling to potential acquisition targets that it favors long-term business relationships and of leaving Warren Buffett's minimalist mark on every aspect of the company's culturestrategies that, rightly or wrongly, have been wildly attractive to investors.

\section{B. Philip Morris International and Northrop Grumman}

As behemoths of the tobacco and defense industries, respectively, Philip Morris International ${ }^{71}$ and Northrop Grumman ${ }^{72}$ have both recently engaged financing counsel outside the top ranks for multi-billion-dollar loans. For its $\$ 3.5$ billion revolving credit facility in 2015, Philip Morris chose Hunton \& Williams LLP, its primary and longstanding U.S. relationship firm. In contrast, Northrop Grumman does not appear to have relied on a relationship firm for its $\$ 1.5$ billion loan in 2011: based on searches of the public record, the interactions between the company and its selected counsel, Sheppard, Mullin, Richter \& Hampton LLP, are limited and of relatively recent origin. In both cases, geographic proximity appears to have played a role: Philip Morris's U.S. operations and Hunton \& Williams are both products of Richmond, Virginia, ${ }^{73}$ while Sheppard Mullin ${ }^{74}$ and Northrop Grumman ${ }^{75}$ were both founded in the Los Angeles area, where Northrop Grumman was also headquartered until

70 See Cunningham, supra note 63, at 105.

71 See Credit Agreement Relating to a US\$3,500,000,000 Revolving Credit Facility Among

Philip Morris International Inc., The Initial Lenders Named Therein, Citibank International Limited, and Citibank, N.A. (Oct. 1, 2015), available at https://www.sec.gov/Archives/edgar/data/1413329/000119312515337340/d49908dex101.h $\underline{\mathrm{tm}}$.

72 See Second Amended and Restated Credit Agreement Among Northrop Grumman Corporation, The Lenders Party Thereto, and JPMorgan Chase Bank, N.A. (Sept. 8, 2011) (hereinafter "Northrop Grumman Credit Agreement"), available at http://sec.gov/Archives/edgar/data/1133421/000119312511247019/d230126dex101.htm.

73 See http://www.vault.com/company-profiles/law/hunton-williams-llp/companyoverview.aspx.

${ }^{74}$ See http:/ /www.vault.com/company-profiles/law/sheppard-mullin-richter-hamptonllp/company-overview.aspx.

75 See Northrop Grumman Corporation, Annual Report (Form 10-K) (Feb. 2, 2015) at 1, available at http://www.sec.gov/Archives/edgar/data/1133421/000113342115000008/noc$\underline{12312014 \times 10 \mathrm{k} . \mathrm{htm}}$. 
recently.

Both Northrop Grumman and Philip Morris operate in industries with significant regulatory burdens and public or private enforcement risk. Further, as a defense firm, much of Northrop Grumman's work product and contracts cannot be publicly disclosed, ${ }^{76}$ and approximately 85 percent of its sales are to a single customer-the U.S. government-further complicating the task of securing financing. ${ }^{77}$ Companies operating in a costly and highly specialized regulatory environment are surely potential candidates for either (1) developing close, long-term relationships with a small number of law firms or (2) steering work to a large in-house staff. Here, Philip Morris opted for the first strategy, while Northrop Grumman appears to have chosen the second. ${ }^{78}$

When is a client justified in using a relationship firm over superior finance counsel? The advantage of relationship firms is their intimate knowledge of their clients, including in particular their unique regulatory and litigation risks. Yet even accepting that Philip Morris has benefitted from cultivating a relationship firm in the first place, it is unclear why this would preclude it from using elite financing counsel in a one-off transaction-or, in fact, from using both its relationship firm and elite financing counsel-particularly for a loan of this size.

Northrop Grumman's decision to rely on the combination of in-house counsel and a firm with relatively little experience in syndicated lending is also surprising. ${ }^{79}$ Because out-of-pocket transaction costs are small in proportion to loans of this size, Northrop Grumman could have engaged elite finance counsel to complement its in-house regulatory expertise. In fact, the company subsequently did just that: it used top-ranked Cravath, Swaine \& Moore LLP for each of its three syndicated loan financings in 2012, 2013, and 2015. ${ }^{80}$

${ }^{76}$ See $i d$. at 5 (referring to the company's "restricted" programs).

77 Id. at 7.

78 The fact that one of the borrower's legal opinions was provided by an officer of Northrop Grumman suggests that its in-house lawyers were involved in the financing. See Northrop Grumman Credit Agreement, supra note 68.

79 The Sheppard Mullin website touts the firm's experience with government contracting and corporate transactions for the aerospace and defense industry. See http://www.sheppardmullin.com/aerospace-and-defense (last visited December 2, 2015) ("Our attorneys have 100+ years combined experience serving aerospace and defense industry clients...We know the industry and the environment in which participants compete.”).

80 See 364-Day Credit Agreement Among Northrop Grumman Corporation, The Lenders Party Thereto, and JPMorgan Chase Bank, N.A. (Sept. 4, 2012), available at http://www.sec.gov/Archives/edgar/data/1133421/000113342112000038/exhibit101.htm; Credit Agreement Among Northrop Grumman Corporation, The Lenders Party Thereto, and JPMorgan Chase Bank, N.A. (Aug. 29, 2013), available at http://www.sec.gov/Archives/edgar/data/1133421/000119312513353825/d591544dex101.h tm; Amended and Restated Credit Agreement Among Northrop Grumman Corporation, The Lenders Party Thereto, and JPMorgan Chase Bank, N.A. (Jul. 8, 2015), available at https://www.sec.gov/Archives/edgar/data/1133421/000119312515249197/d95748dex101.h tm. 
Because the defense and tobacco industries are considered unsavory by some, an alternative explanation would be that the most elite law firms were simply less willing to provide legal services to these two companies. The motive for law firms to avoid such clients involves some combination of reputational concerns, the express or implied wishes of existing clients engaged in socially responsible investing (such as pension funds, foundations, and university endowments), and the firms' recruiting appeal to graduates of the most elite law schools. There does not appear to be any evidence that these companies are indeed "untouchables" from law firms' perspective, however. In other contexts such as litigation, it is routinely assumed that the lure of immediate profits generally outweighs law firms' qualms about their clients' reputations. In both cases, then, we are simply left to wonder whether behavioral factors (such as inertia or personal preferences) or agency costs played any role in the selection of counsel.

\section{Lowe's}

For its $\$ 1.75$ billion credit facility, which closed in August 2014, Lowe's Companies relied on Moore \& Van Allen PLLC, ${ }^{81}$ a Charlotte-based law firm with just over 300 attorneys across its various offices. Lowe's itself is headquartered just outside of Charlotte, in Moorseville, North Carolina. Lowe's Companies' choice of finance counsel is striking, and not simply as another apparent example of relationship lawyering. (Moore \& Van Allen has represented Lowe's in prior financings.) Particularly intriguing is the fact that Moore \& Van Allen known for representing lenders and underwriters, rather than borrowers. (In the year in which the Lowe's credit facility closed, by syndicated-loan volume Moore \& Van Allen was ranked $17^{\text {th }}$ among all U.S. law firms for lender-side representation and $86^{\text {th }}$ for borrower-side representation.) With major lender clients such as Bank of America, Moore \& Van Allen has a well-established reputation for elite-quality lending work.

Among law firms, there is a divide between those that tend to represent major borrowers (such as private equity firms and Fortune 500 operating companies) and those that tend to represent the major banks that arrange or underwrite their loans. ${ }^{82}$ Of course, experience with lender-side work is undoubtedly useful for borrower-side work as well. Rather, the concern from

81 See Credit Agreement Among Lowe's Companies, Inc., Bank of America, N.A., and The Other Lenders Party Thereto (Aug. 29, 2014), available at https://www.sec.gov/Archives/edgar/data/60667/000006066714000146/exhibit101.htm.

82 The same type of divide holds true to a lesser extent for mergers and acquisitions, with certain firms developing reputations for representing financial buyers such as private equity firms, and others specializing in representing major operating companies on the sell-side. See Davidoff, supra note 25. 
the client's perspective with crossing the divide should be that, for reputational reasons, a lender-side firm might not be willing to bargain aggressively when representing a borrower, in order to protect its standard negotiating positions when it represents lenders. Thus, in this instance, the company chose a law firm that had business interests potentially adverse to its own.

To conclude this Part III, these four case studies highlight the wide range of motivations for companies to select their counsel. For loans exceeding a billion dollars, the economic calculus would seem relatively straightforward: borrowing companies should engage elite financing counsel, because, given the transaction size, the expected benefit in transaction terms should outweigh the negligible difference in legal fees. Yet in each of these four cases, a major public company chose financing counsel outside the top rankings to represent it, and in at least one case also relied on its in-house staff. While we cannot draw definitive conclusions from case studies, these examples illustrate that, in practice, many factors falling outside a one-off, transaction-specific costbenefit analysis can affect major companies' choice of counsel.

\section{CONCLUSION}

The global financial crisis prompted corporate America to take a hard look at the fees charged by its law firms. The continuing clamor for lower legal fees has already prompted significant changes in the operations and work product of corporate law firms and in companies' processes for hiring them. But are we headed in the right direction? Within this context, empirical studies of law firm selection are long overdue. When faced with a range in quality, how do corporate clients select among law firms, and are such selections valuemaximizing? This Article finds a substantial discrepancy between the choice of counsel of private equity firms and public companies for major financing transactions. While this result alone does not identify what motivates law-firm selection, it narrows the set of plausible hypotheses considerably for future work. In addition, it suggests a surprising tendency among large public companies to spend too little on outside counsel for transactional work. While the recent focus on legal fees is both timely and advisable, it should not be understood to justify hiring lower-quality counsel as a rule. 
Appendix A: Regressions with Industry Controls

\begin{tabular}{|c|c|c|c|}
\hline & Top-Firm_1 & Top-Firm_2 & Top-Firm_3 \\
\hline Sponsored & $\begin{array}{c}4.320 \\
(12.43)^{* *}\end{array}$ & $\begin{array}{l}2.921 \\
(7.48)^{* *}\end{array}$ & $\begin{array}{c}3.660 \\
(10.94)^{* *}\end{array}$ \\
\hline $\ln$ (Loan Amount) & $\begin{array}{c}1.572 \\
(10.50)^{* *}\end{array}$ & $\begin{array}{l}1.553 \\
(8.63)^{* *}\end{array}$ & $\begin{array}{c}1.773 \\
(12.77)^{* *}\end{array}$ \\
\hline Acquisition Purpose & $\begin{array}{c}1.003 \\
(0.03)\end{array}$ & $\begin{array}{l}1.026 \\
(0.18)\end{array}$ & $\begin{array}{c}0.964 \\
(0.31)\end{array}$ \\
\hline Secured Loan & $\begin{array}{l}1.650 \\
(4.15)^{* *}\end{array}$ & $\begin{array}{c}1.398 \\
(2.42)^{*}\end{array}$ & $\begin{array}{l}1.617 \\
(3.95)^{* *}\end{array}$ \\
\hline \multicolumn{4}{|l|}{ Industry indicators: } \\
\hline Aerospace and defense & $\begin{array}{c}0.520 \\
(0.73)\end{array}$ & $\begin{array}{c}0.751 \\
(0.30)\end{array}$ & $\begin{array}{c}0.937 \\
(0.08)\end{array}$ \\
\hline Agriculture & $\begin{array}{c}0.389 \\
(1.15)\end{array}$ & $\begin{array}{c}0.172 \\
(1.61)\end{array}$ & $\begin{array}{c}0.158 \\
(1.72)\end{array}$ \\
\hline Automobiles, airlines and transportation & $\begin{array}{c}0.813 \\
(0.77)\end{array}$ & $\begin{array}{c}0.649 \\
(1.38)\end{array}$ & $\begin{array}{l}1.091 \\
(0.33)\end{array}$ \\
\hline Banking and financial services & $\begin{array}{c}0.974 \\
(0.10)\end{array}$ & $\begin{array}{c}0.839 \\
(0.54)\end{array}$ & $\begin{array}{l}1.194 \\
(0.65)\end{array}$ \\
\hline Chemicals & $\begin{array}{c}1.126 \\
(0.39)\end{array}$ & $\begin{array}{l}1.214 \\
(0.57)\end{array}$ & $\begin{array}{l}1.060 \\
(0.19)\end{array}$ \\
\hline Computer and electronic equipment & $\begin{array}{c}0.689 \\
(1.27)\end{array}$ & $\begin{array}{l}0.390 \\
(2.59)^{* *}\end{array}$ & $\begin{array}{c}0.647 \\
(1.47)\end{array}$ \\
\hline Construction and materials & $\begin{array}{l}1.103 \\
(0.32)\end{array}$ & $\begin{array}{c}0.998 \\
(0.01)\end{array}$ & $\begin{array}{c}0.960 \\
(0.13)\end{array}$ \\
\hline Consumer goods & $\begin{array}{l}1.008 \\
(0.02)\end{array}$ & $\begin{array}{c}2.553 \\
(2.23)^{*}\end{array}$ & $\begin{array}{l}1.024 \\
(0.07)\end{array}$ \\
\hline Food and beverage & $\begin{array}{c}0.509 \\
(1.95)\end{array}$ & $\begin{array}{c}0.708 \\
(0.91)\end{array}$ & $\begin{array}{c}0.406 \\
(2.52)^{*}\end{array}$ \\
\hline Forestry and paper & $\begin{array}{c}0.343 \\
(2.21)^{*}\end{array}$ & $\begin{array}{c}0.263 \\
(2.18)^{*}\end{array}$ & $\begin{array}{c}0.484 \\
(1.62)\end{array}$ \\
\hline Insurance & $\begin{array}{c}0.840 \\
(0.43)\end{array}$ & $\begin{array}{c}0.903 \\
(0.22)\end{array}$ & $\begin{array}{l}1.330 \\
(0.75)\end{array}$ \\
\hline Manufacturing and machinery & $\begin{array}{c}0.697 \\
(1.20)\end{array}$ & $\begin{array}{l}0.614 \\
(1.35)\end{array}$ & $\begin{array}{c}0.617 \\
(1.58)\end{array}$ \\
\hline Media and entertainment & $\begin{array}{l}1.100 \\
(0.32)\end{array}$ & $\begin{array}{l}1.137 \\
(0.35)\end{array}$ & $\begin{array}{l}1.293 \\
(0.85)\end{array}$ \\
\hline Medical devices and healthcare & $\begin{array}{c}0.822 \\
(0.71)\end{array}$ & $\begin{array}{c}0.735 \\
(0.97)\end{array}$ & $\begin{array}{c}0.870 \\
(0.51)\end{array}$ \\
\hline Mining and metals & $\begin{array}{c}0.774 \\
(0.90)\end{array}$ & $\begin{array}{c}0.793 \\
(0.70)\end{array}$ & $\begin{array}{c}0.786 \\
(0.85)\end{array}$ \\
\hline Oil and gas & $\begin{array}{l}1.313 \\
(1.13)\end{array}$ & $\begin{array}{c}0.816 \\
(0.72)\end{array}$ & $\begin{array}{l}0.392 \\
(3.57)^{* *}\end{array}$ \\
\hline Pharmaceuticals and biotechnology & $\begin{array}{l}1.534 \\
(1.20)\end{array}$ & $\begin{array}{c}0.861 \\
(0.33)\end{array}$ & $\begin{array}{l}1.558 \\
(1.23)\end{array}$ \\
\hline Real estate & $\begin{array}{l}0.468 \\
(2.93)^{* *}\end{array}$ & $\begin{array}{l}0.462 \\
(2.68)^{* *}\end{array}$ & $\begin{array}{l}0.433 \\
(3.21)^{* *}\end{array}$ \\
\hline Retailers & $\begin{array}{c}0.740 \\
(1.19)\end{array}$ & $\begin{array}{c}0.809 \\
(0.73)\end{array}$ & $\begin{array}{c}0.736 \\
(1.21)\end{array}$ \\
\hline Services & $\begin{array}{c}0.655 \\
(1.80)\end{array}$ & $\begin{array}{c}0.531 \\
(2.33)^{*}\end{array}$ & $\begin{array}{c}0.655 \\
(1.81)\end{array}$ \\
\hline Telecommunications & $\begin{array}{l}1.038 \\
(0.11)\end{array}$ & $\begin{array}{c}0.809 \\
(0.50)\end{array}$ & $\begin{array}{l}1.022 \\
(0.06)\end{array}$ \\
\hline Textiles and apparel & $\begin{array}{c}1.717 \\
(1.45)\end{array}$ & $\begin{array}{c}0.631 \\
(0.98)\end{array}$ & $\begin{array}{l}1.666 \\
(1.37)\end{array}$ \\
\hline Travel and leisure & $\begin{array}{c}1.010 \\
(0.03)\end{array}$ & $\begin{array}{c}0.878 \\
(0.28)\end{array}$ & $\begin{array}{c}0.562 \\
(1.45)\end{array}$ \\
\hline $\boldsymbol{N}$ & 2,979 & 1,970 & 2,979 \\
\hline
\end{tabular}

